\title{
Representasi Relasi Kuasa Dalam Kelompok Masyarakat Pada Film Tilik
}

\author{
Fairuz Arta Abhipraya*, Muhammad Iqbal Khatami, Muhammad Hima El Muntaha \\ Universitas Muhammadiyah Yogyakarta, Yogyakarta, Indonesia. \\ *e-mail: fairuz.arta.fisip17@mail.umy.ac.id
}

\begin{abstract}
This article explained about the representation of power relations over information conducted in social group which contains group of mothers in a short movie titled Tilik. This article is communication research, because the representation of power relations presented in this short movie can be constructed through scenes in the form of signs that can also be interpreted and analyzed. The problem formulation in this article is how the representation of power relations in the short film titled Tilik? Researcher use some literature review in this article such as about representations, power relations over information, and constructiveness in movie, movie as social realities, characters in movie sections, and political agendas depicted in movie. The method used to analysis in this research is Vladimir Propp's narrative method and Michel Foucault's theory of power relations. The power relation that is presented in this short movie is the power over the information that is owned by Bu Tejo to the social groups of mothers who are involved in the movie, this is shown by several parts of the movie that were deliberately selected by the researcher as material for analysis. This study resulted in the conclusion that the representation of power relations is held dominantly by Bu Tejo, because Bu Tejo had information that is not owned by other social groups of mothers. On the other hand, Bu Tejo's power relation is useful for strengthening social ties in order to garnering electoral support for her husband in the upcoming local head of village election and get rid of distraction in society.
\end{abstract}

Keywords: Power Relations; Tilik; Short Movie; Group of Mothers; Vladimir Propp

\begin{abstract}
ABSTRAK
Artikel ini menjelaskan tentang representasi relasi kuasa atas informasi yang dimiliki di kelompok sosial masyarakat yang berisikan oleh ibu-ibu dalam film pendek dengan tajuk Tilik. Artikel ini merupakan sebuah penelitian komunikasi, sebab representasi relasi kuasa yang dihadirkan pada film pendek dengan tajuk Tilik ini dapat dikonstruksi melalui adegan berupa tanda-tanda yang bisa dapat dimaknai serta analisis. Rumusan masalah yang dihadirkan oleh peneliti dalam artikel ini adalah bagaimana representasi relasi kuasa dalam film pendek dengan tajuk Tilik? Peneliti menggunakan tinjauan pustaka representasi mengenai relasi kuasa atas informasi dan konstruksional dalam film, film sebagai realitas sosial masyarakat, karakter dalam bagian film, dan agenda politik yang digambarkan pada film. Metode yang digunakan untuk menganalisis film adalah metode naratif milik Vladimir Propp dan teori relasi kuasa milik Michel Foucault. Relasi kuasa yang dihadirkan pada film ini adalah kuasa atas informasi yang dimiliki oleh $\mathrm{Bu}$ Tejo kepada kelompok sosial ibu-ibu yang terlibat di dalam film, hal ini ditunjukkan oleh beberapa bagian film yang sengaja dipilih oleh peneliti sebagai bahan analisis. Penelitian ini menghasilkan kesimpulan bahwa representasi relasi kuasa dipegang secara dominan oleh $\mathrm{Bu}$ Tejo, pasalnya $\mathrm{Bu}$ Tejo memiliki informasi yang tidak dimiliki oleh kelompok sosial ibu-ibu yang lain. Disisi lain relasi kuasa Bu Tejo berguna untuk mengeratkan ikatan sosial untuk menggalang dukungan elektoral untuk suaminya di pemilihan Lurah mendatang dan menyingkirkan distraksi di dalam kelompok masyarakat.
\end{abstract}

Kata Kunci: Relasi Kuasa; Tilik; Film Pendek; Ibu-ibu; Vladmir Propp

\section{Pendahuluan}

Pembahasan mengenai bagaimana sebuah sudah tidak asing lagi, pasalnya film sengaja dirancang sebagai alat untuk menyampaikan 
media cerita yang sudah di konsepkan secara matang. Selaras dengan itu, wajar saja jika kita turut memberikan persetujuan bahwa film adalah salah satu media untuk para seniman, penulis naskah, dan semua orang yang terlibat di dalamnya untuk bisa menuangkan ekspresi nya melalui film yang digarap. Seperti halnya naskah film pendek yang ditulis oleh Bagus Sumartono dengan judul "Tilik" yang rilis pada 17 Agustus 2020 di YouTube, Bagus Sumartono berhasil menggambarkan dengan sangat baik ekspresi dan kebiasaan masyarakat Indonesia di dalam film dengan tajuk "Tilik" tersebut.

Film ini menceritakan tentang bagaimana sebuah kelompok sosial masyarakat desa yang didominasi oleh ibu-ibu mencoba untuk menjenguk salah satu orang yang tengah sakit dan orang tersebut merupakan bagian dari kelompok tersebut di sebuah rumah sakit, orang tersebut digambarkan sebagai orang yang memiliki jabatan tertinggi di kelompok tersebut yaitu sebagai lurah di sebuah desa tempat kelompok sosial masyarakat tersebut tinggal. Dalam upayanya untuk menjenguk 'bu lurah', kelompok sosial tersebut menggunakan kendaraan truk pengangkut barang untuk menuju rumah sakit. Hal ini terjadi akibat dari keadaan darurat yang membuat mereka tidak bisa memesan kendaraan berskala besar yang layak seperti bus untuk pergi ke rumah sakit untuk menjenguk 'bu lurah'. Di dalam perjalanan menuju rumah sakit, terjadi konflik internal di dalam kelompok sosial masyarakat tersebut, hal ini dipicu oleh salah satu orang dengan nama 'Bu Tejo' yang acap kali bergosip mengenai orang lain di dalam truck pengangkut barang tersebut, sehingga salah satu dari kelompok sosial masyarakat tersebut tidak E-ISSN: 2580-6955 suka akan hal tersebut sehingga terjadilah sebuah konflik.

Film ini tidak hanya menceritakan tentang bagaimana kebiasaan masyarakat Indonesia yang gemar bergosip dan memiliki jiwa sosial yang tinggi ketika ada salah satu orang dari kelompok sosial mereka sakit, namun ada sebuah gambaran mengenai relasi kuasa yang tengah dibangun oleh karakter di dalam film tersebut. Sebuah film yang berhasil digarap memaparkan sebuah realitas simbolik yang menjadi representasi akan sebuah realitas faktual, realitas faktual ini menggambarkan bagaimana keadaan lingkungan sosial yang sebenarnya terjadi di masyarakat.

Menurut Fiske pada 1996 di dalam (Fitriasari, 2016), menjelaskan bahwa dalam sebuah proses untuk memproduksi dari sebuah realitas simbolik, ada peran interaksi simbolik yang berhasil dibentuk oleh bahasa dan konvensi. Sebuah film selalu menangkap realitas sosial yang tengah berkembang di tengah masyarakat, dan selanjutnya dengan tujuan untuk memberikan proyeksi secara luas dengan mengangkatnya di dalam sebuah layar lebar (Sobur, 2003). Sebuah karya film juga bisa dimaknai sebagai sebuah penggambaran kembali kehidupan sosial masyarakat (fragmen), salah satu bentuk fragmen yang acap kali diwakili dalam sebuah film adalah mengenai fenomena kehidupan bersosialisasi antar individu di dalam sebuah kelompok masyarakat, bentuk yang diwakilinya akan sering muncul dalam bentuk sebuah dukungan, tolakan, kritikan, atau mungkin bisa saja hanya netral/tidak memihak. Nampak semakin membuat jelas yang dipaparkan oleh Stuart Hall pada 1997 di dalam Fitriasari (Fitriasari, 2016) bahwa 
sebuah proses dimana arti (meaning) dihasilkan dengan penggunaan Bahasa dan terjadi pertukaran antar anggota kelompok masyarakat di dalam sebuah budaya (culture), sehingga kita mudah untuk memahami antara kejadian nyata dan tidak nyata (fictional).

Di dalam sebuah film yang menggambarkan realitas sosial masyarakat yang diangkat di sebuah layar lebar, interaksi sosial antar individu juga tidak lepas berperan di dalamnya. Berbagai aktivitas di dalam kelompok selalu diawali dengan sebuah interaksi sosial, Gillin di dalam Soekanto (Soekanto, 1990:489) menjelaskan bahwa interaksi sosial adalah hubungan-hubungan sosial yang dinamis terkait dengan hubungan antara individu kepada individu lain, individu kepada kelompok lain, dan kelompok kepada kelompok lain. Sejalan dengan itu, di dalam Soekanto (Soekanto, 1990:61) juga menjelaskan bahwa interaksi sosial akan dimulai ketika ada dua orang yang bertemu. Interaksi sosial nampaknya sudah menjadi sebuah kebutuhan bagi manusia sebagai mahluk sosial, bentuknya bisa bermacam, bisa seperti interaksi dalam kelompok kerabat, teman sekantor, perkumpulan dan lain sebagainya (Soemardjan \& Soemardi, 1964). Kegiatan yang paling melekat dalam budaya masyarakat adalah kegiatan bergosip, kegiatan ini juga termasuk dalam sebuah interaksi sosial di dalam kelompok masyarakat. Film pendek Tilik menjadi sangat menarik untuk di teliti karena film ini merupakan karya film pendek yang sangat viral semenjak pertama kali dirilis, dan bahkan aktor-aktornya sering menjadi "meme" yang sengaja dibuat untuk mempresentasikan hal lucu masyarakat Indonesia. Selaras dengan hal tersebut, film E-ISSN: 2580-6955 pendek Tilik menjadi sangat menarik manakala dapat menjadi sebuah representasi kebiasaan masyarakat Indonesia yang gemar melakukan kegiatan gosip, sehingga pesan yang disampaikan di dalam materi film menjadi perwakilan kebiasaan yang kuat pada masyarakat Indonesia, dialog antara pemain dalam film tersebut merupakan representasi kehidupan keseharian dan memiliki nilai kepentingan.

Di dalam sebuah interaksi sosial pada masyarakat, terdapat sebuah relasi yang memiliki keterkaitan satu sama lain namun tidak merata peran nya, dengan kata lain ada yang dikuasai dan ada yang menguasai karena pengetahuan. Seperti yang diungkapkan oleh Michel Foucault sebagai seorang filsuf sekaligus pelopor konsep strukturalisme yang sangat tertarik mengkaji tentang hubungan antara kuasa dan pengetahuan. Singkatnya adalah tidak ada praktek pelaksanaan kekuasaan yang tidak memunculkan pengetahuan dan tidak ada pengetahuan yang di dalamnya tidak memandang relasi kuasa (Foucault \& Muzir, 2002). Foucault berhasil memaparkan secara baik bahwa individu modern muncul sebagai objek dan subjek dari penyebaran dan pengadaan jaringjaring kuasa. Menurut pandangan Foucault, kehadiran dari kekuasaan tersebar dimana-mana, pasalnya kekuasaan adalah satu dimensi dari satu relasi yang terpadu. Artinya bahwa dimana ada sebuah relasi, maka ada sebuah kekuasaan di dalamnya (Susilo \& Kodir, 2016). Foucault memberi pengakuannya bahwa ada kehadiran dari sekian banyak kekuatan dan kuasa yang tersebar secara luas dalam relasi antar manusia. Semua kekuatan dan kuasa itu dapat ditemukan dai berbagai aspek relasi antar manusia, contohnya seperti relasi antara manusia satu dengan manusia 
lainnya dan relasi antar manusia dengan lingkungannya/situasi mereka (Bertens. K, 2001). Apa yang disampaikan oleh Foucault lebih membahas mengenai bagaimana sebuah kuasa dapat berfungsi di bidang tertentu, bukan tentang bagaimana mengurai konsep kuasa (Mudhoffir, 2013).

Konsep relasi kuasa yang digunakan di dalam menganalisis sebuah film sudah banyak diterapkan oleh para peneliti, seperti di dalam (Humairoh \& Chirstantyawati, 2018) yang menggambarkan keterlibatan relasi kuasa negara adidaya Amerika atas kekuatan yang dimilikinya terhadap negara-negara di dunia pada film Geostorm. Selanjutnya juga analisis relasi kuasa oleh (Nugroho, 2019) telah mengambarkan bagaimana pemilihan diksi kata dalam sebuah acara TV juga berpengaruh terhadap penguatan kuasa pada isu gender. Dalam skala yang lebih luas, analisis dari (Syahputra, 2017) menyambangi kekuatan media untuk menciptakan relasi kuasa antar media dan masyarakat atas informasi yang dimiliki media. Dari penelitian terdahulu yang terkait dengan bagaimana representasi relasi kuasa pada sebuah informasi, peneliti mencoba mengisi gap penelitian tersebut dengan mencoba menelisik sebuah bentuk relasi kuasa pada sebuah film pendek dengan judul Tilik yang tengah menjadi perbincangan publik.

Berbagai tokoh yang memiliki karakter dan sifat yang berbeda-beda di dalam narasi sebuah film turut berkontribusi untuk menggambarkan realitas dan memudahkan pengarang naskah film untuk mengutarakan isi dari idenya. Vladimir Propp selaku folktale atau yang dikenal sebagai peneliti dongeng, telah memberikan susunan jenis E-ISSN: 2580-6955 dari berbagai karakter di setiap narasi yang ditelitinya, yang kemudia narasi tersebut dibagi menjadi beberapa bagian. Propp mengenalkan konsep karakter dan fungsi pada berbagai jenis cerita rakyat, baik modern maupun yang klasik (Eriyanto, 2015). Fungsi memiliki dua aspek penting yang perlu ditinjau, yang pertama adalah tindakan yang dilakukan karakter lain sehingga menciptakan arti/makna yang ingin disampaikan oleh penulis narasi, sedangkan yang kedua adalah karena aksi dari narasi yang dibuat maka aksi dari karakter akan memberi pengaruh terhadap karakter lainnya.

\section{Bagan.1 Kerangka Konseptual Penelitian}

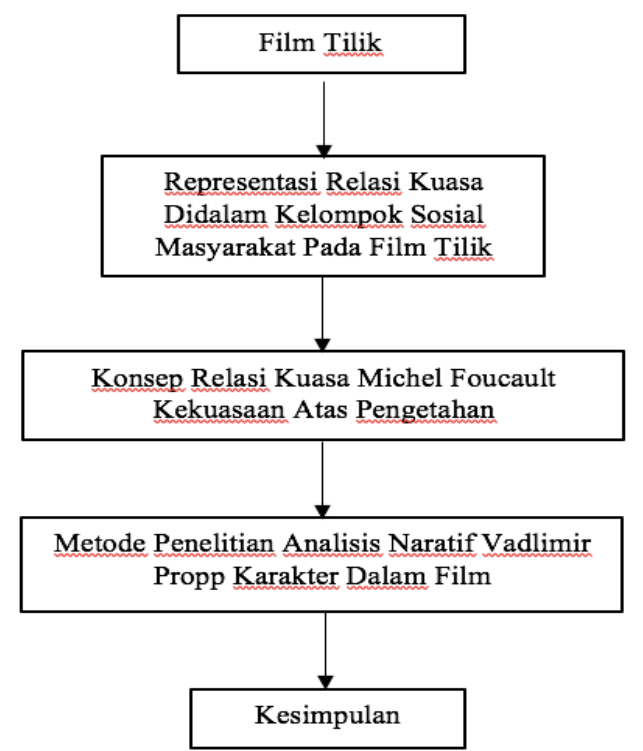

Propp memaparkan konsep fungsinya yang merupakan narasi sempurna, dengan artian bahwa fungsi dan karakter semuanya terdapat dalam rangkaian cerita. Propp secara gamblang di dalam sebuah narasi telah memberikan klasifikasi sebanyak 7 (tujuh) jenis karakter. Jenis riset naratif memang masih digandrungi serta menjadi landasan para peneliti yang mencoba menganalisis narasi di dalam sebuah film, karena pada dasarnya fungsi pokok naratif adalah untuk mendorong keteraturan pada hal-hal yang 
tidak/kurang teratur sehingga mudah untuk dipahami. Propp yang memperkenalkan pola struktur naratif ini telah berhasil mengilhami banyak aktor yang tertarik dalam mengkaji berbagai karya (Sobur, 2014). Propp dengan pola struktur naratif nya secara umum telah membaginya menjadi tiga bagian yaitu permulaan, pertengahan, dan penutup. Permulaan hanya berisi seperempat bagian dari keseluruhan panjang filmnya, pertengahan adalah berisi lebih dari setengah durasi filmnya atau bahkan lebih, sedangkan penutup adalah bagian akhir dari durasi film (Pratista, 2008). Dengan menggunakan teknik analisis naratif dari Vladimir Propp, beberapa adegan dalam potongan film pendek ini bisa di analisis. Teknik analisis naratif milik Propp tidak harus digunakan secara berurutan dan tidak harus juga digunakan untuk menganalisis keseluruhan adegan di dalam film dengan tujuan untuk membedah seluruh isi film.

\section{Metode Penelitian}

Artikel ini menggunakan metode penelitian kualitatif, Metode penelitian kualitatif adalah metode penelitian yang dilaksanakan pada setting tertentu yang terjadi dalam kehidupan nyata dengan fokus untuk menyelidiki dan memahami sebuah fenomena, seperti apa yang terjadi, mengapa itu terjadi, dan bagaimana itu terjadi (Chariri, 2009). Sedangkan teknik analisis yang digunakan dalam penelitian ini adalah teknik analisis naratif milik Vladimir Propp, Dengan menggunakan teknik analisis naratif dari Vladimir Propp, beberapa adegan dalam potongan film pendek ini bisa di analisis (Eriyanto, 2015).

Objek penelitian ini ialah film pendek dengan tajuk Tilik yang bercerita tentang budaya masyarakat jawa yang gemar menengok kerabatnya yang sakit dengan bergerombol (beramai-ramai), hal yang ditonjolkan sudah tentu bagaimana mereka menggunakan truck sebagai alat transportasinya. Namun dalam upaya untuk menjenguk kerabatnya, perdebatan panjang pun terjadi karena salah satu karakter melakukan kegiatan bergosip dan menimbulkan konflik karena ada yang tidak setuju akan informasi yang disampaikan dalam gosip. Teknik untuk mengambil sampel adalah purposive sampling. Populasi penelitian ini adalah beberapa bagian dari film pendek dengan tajuk Tilik yang dirilis tahun 2020. Sampel yang diambil oleh peneliti telah berdasarkan kriteria, yaitu terdapat adegan yang menggambarkan relasi kuasa dan berdasarkan kriteria dari teknik naratif milik Vladimir Propp.

\section{Hasil Penelitian dan Pembahasan}

Ada 7 karakter utama yang menjadi kunci dalam konsep naratif milik Vladimir Propp, karakter-karakter tersebut disesuaikan di dalam narasi film, keterangannya yakni sebagai berikut:

\begin{tabular}{lll}
\hline \multicolumn{1}{c}{ Karakter } & Simbol Fungsi & \multicolumn{1}{c}{ Deskripsi } \\
\hline Penjahat & Bu Tejo & $\begin{array}{l}\text { Melakukan kegiatan bergosip untuk menghasut ibu-ibu } \\
\text { lainnya agar terhindar dari perilaku Dian yang dianggap } \\
\text { dapat mengancam kehidupan mereka, yang mana kegiatan } \\
\text { bergosip dinilai sebagai kegiatan yang negative di dalam } \\
\text { film tersebut. }\end{array}$ \\
& & $\begin{array}{l}\text { Memberikan bingkisan berupa hal yang akan berguna bagi } \\
\text { polisi dengan tujuan agar terhindar dari hukuman tilang }\end{array}$
\end{tabular}




\begin{tabular}{|c|c|c|}
\hline Karakter & Simbol Fungsi & Deskripsi \\
\hline Penolong & Fikri & $\begin{array}{l}\text { Mengantarkan dan menjaga Bu Lurah saat sedang sakit di } \\
\text { rumah sakit. }\end{array}$ \\
\hline Putri & $\begin{array}{l}\text { Informasi } \\
\text { Tentang Dian }\end{array}$ & $\begin{array}{l}\text { Informasi tentang Dian di dalam film Tilik mendominasi } \\
\text { sebagai objek topik percakapan utama yang tengah } \\
\text { diperbincangkan, topik tentang apa yang dilakukan Dian } \\
\text { menjadi sorotan karena para aktor berusaha mencari } \\
\text { informasi sebanyak-banyaknya tentang Dian. }\end{array}$ \\
\hline Pengirim & Gotrek & $\begin{array}{l}\text { Mengantarkan ibu-ibu ke rumah sakit menggunakan } \\
\text { angkutan truck untuk menjenguk Bu Lurah. }\end{array}$ \\
\hline Pahlawan & Yu Ning & $\begin{array}{l}\text { Mencoba menyelamatkan Dian dari prasangka buruk gosip } \\
\text { dari ibu-ibu. Memberikan nasehat kepada Bu Tejo dan Ibu- } \\
\text { ibu lainnya untuk tidak berprasangka buruk terhadap Dian, } \\
\text { meskipun apa yang digosipkan ternyata benar. }\end{array}$ \\
\hline Pahlawan Palsu & Dian & $\begin{array}{l}\text { Berpura-pura nampak seperti wanita baik-baik didepan } \\
\text { publik khususnya didepan fikri, namun kenyataannya ada } \\
\text { agenda lain untuk menikah bersama ayahnya fikri dan apa } \\
\text { yang digosipkan oleh ibu-ibu ternyata benar. Maka secara } \\
\text { tidak langsung, sosok Dian telah menghianati sosok Yu } \\
\text { Ning sebagai salah satu saudaranya. }\end{array}$ \\
\hline
\end{tabular}

Fungsi Dari Narasi Vladimir Propp Dalam Film Pendek Tilik

Film pendek dengan tajuk "Tilik" berasal dari Bahasa jawa yang artinya adalah "menjenguk" ini merupakan gambaran realitas sosial masyarakat jawa di pedesaan dalam menjenguk kerabatnya yang tengah sakit. Film pendek ini disutradarai oleh Wahyu Agung Prasetyo yang rilis pada 17 Agustus 2020. Dalam film ini menceritakan segerombolan ibu-ibu yang tengah dalam perjalanan di dalam truck guna menuju rumah sakit untuk menjenguk Bu Lurah sebagai salah satu orang yang dihormati di kelompok mereka.

Kesempatan berkumpul ini digunakan oleh $\mathrm{Bu}$ Tejo yang digambarkan sebagian karakter penjahat untuk melakukan kegiatan bergosip dengan menyebarkan segala informasi yang dia ketahui tentang objek yang dijadikan bahan bergosip yaitu Dian, di dalam film terlihat jika $\mathrm{Bu}$ Tejo berhasil menghasut beberapa ibu-ibu melalui media bergosip dengan informasi negatif tentang
Dian yang dimilikinya. Akan tetapi, di dalam kelompok ibu-ibu tersebut ada Yu Ning yang memiliki karakter sebagai pahlawan dengan tujuan untuk menghentikan kegiatan bergosip yang dilakukan $\mathrm{Bu}$ Tejo karena informasi yang disampaikan dinilai belum valid. Dengan menggunakan teknik analisis naratif dari Vladimir Propp, beberapa adegan dalam potongan film pendek ini bisa di analisis. Teknik analisis naratif milik Propp tidak harus digunakan secara berurutan dan tidak harus juga digunakan untuk menganalisis keseluruhan adegan di dalam film dengan tujuan untuk membedah seluruh isi film. Berikut ini adalah analisis film pendek Tilik dengan menggunakan fungsi narasi Propp:

\section{Gambar.1}

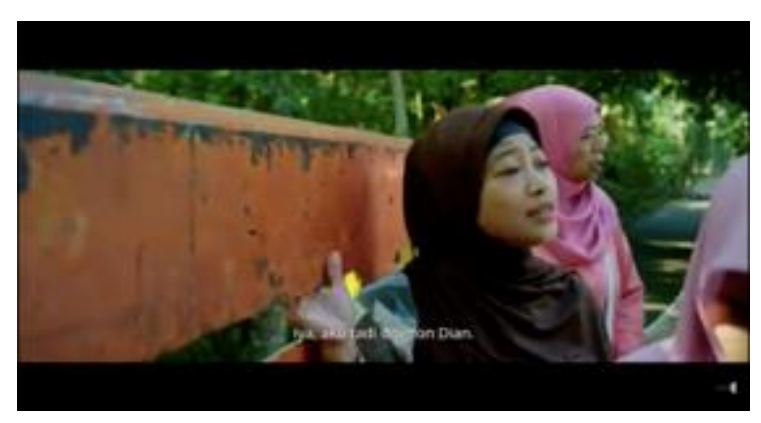




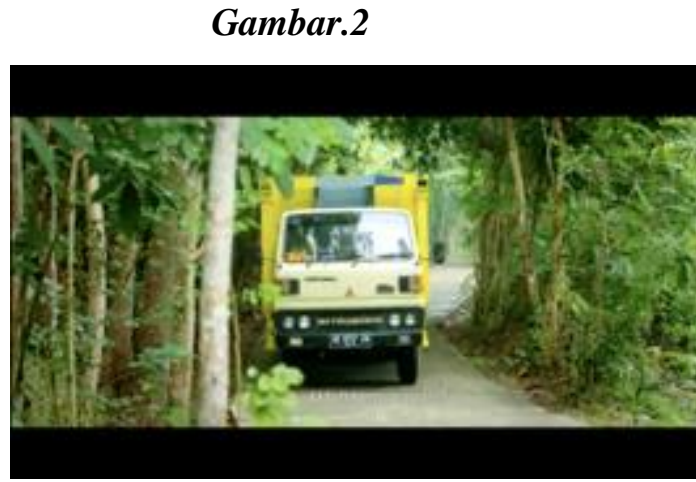

Situasi Awal $(\alpha)$

\begin{tabular}{lll}
\hline Simbol & $\begin{array}{c}\text { Deskripsi } \\
\text { Fungsi }\end{array}$ & \multicolumn{1}{c}{$\begin{array}{c}\text { Deskriptif } \\
\text { Fungsi }\end{array}$} \\
\hline$\alpha$ & Situasi Awal & $\begin{array}{l}\text { Perkenalan } \\
\text { Sosok } \\
\end{array}$ \\
& & Pahlawan \\
\hline
\end{tabular}

\begin{tabular}{l}
\hline Deskripsi \\
\hline Pada awal pembukaan film pendek ini, telah \\
digambarkan tentang bagaimana kelompok \\
ibu-ibu menggunakan truck untuk pergi \\
menjenguk salah satu kerabatnya yaitu Bu \\
Lurah di rumah sakit. Pada bagian ini sosok \\
kepahlawanan sudah dikenalkan oleh narasi \\
cerita film, sosok pahlawan ini dikenalkan \\
sebagai Yu Ning seorang ibu-ibu yang \\
memiliki hubungan darah dengan Dian sebagai \\
karakter pahlawan palsu. Sosok kepahlawanan \\
Yu Ning terlihat di bagian awal ketika menepis \\
beberapa prasangka buruk tentang Dian yang \\
disampaikan oleh Bu Tejo kepada ibu-ibu, Yu \\
Ning mencoba untuk melindungi citra Dian dan \\
di sisi lain Yu Ning beranggapan bahwa \\
bergosip adalah kegiatan tidak terpuji. Yu Ning \\
nantinya akan memiliki satu rekan yang \\
bernama Yu Sum yang juga turut andil pada \\
pihak Yu Ning, namun sosok Yu Sum terlihat \\
lemah dan tidak memiliki pendirian.
\end{tabular}

\section{Pelanggaran $(\gamma)$}

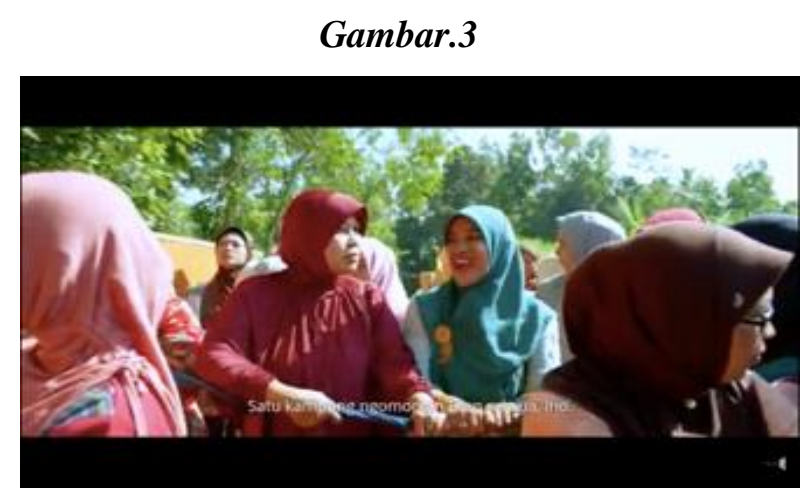

\begin{tabular}{lll}
\hline Simbol & $\begin{array}{c}\text { Deskripsi } \\
\text { Fungsi }\end{array}$ & $\begin{array}{c}\text { Deskriptif } \\
\text { Fungsi }\end{array}$ \\
\hline$\gamma$ & Pelanggaran & Larangan \\
& & yang \\
& & ditujukan \\
& & kepada \\
& & pahlawan \\
\hline
\end{tabular}

Deskripsi
pahlawan dianggap menyimpang dari pemikiran dan informasi yang disampaikan oleh $\mathrm{Bu}$ Tejo tentang Dian. Bu Tejo yang berperan sebagai penjahat memiliki kuasa lebih atas kelompok ibu-ibu karena informasi yang dimilikinya tentang Dian dan $\mathrm{Bu}$ Tejo menyebarkannya secara tidak teratur. Hal ini terlihat ketika Bu Tejo mampu mempengaruhi ibu-ibu lainnya untuk percaya akan informasinya dan mendukung argument $\mathrm{Bu}$ Tejo, sehingga dengan mudah $\mathrm{Bu}$ Tejo bisa membantah apa yang disampaikan oleh $\mathrm{Yu}$ Ning sebagai sosok pahlawan. Akan tetapi $\mathrm{Yu}$ Ning tetap berjuang untuk menolak segala tuduhan Bu Tejo kepada Dian, namun Bu Tejo tetap menjadi yang paling lantang untuk menyampaikan informasi tentang Dian.

\section{Penghasutan $(\eta)$}

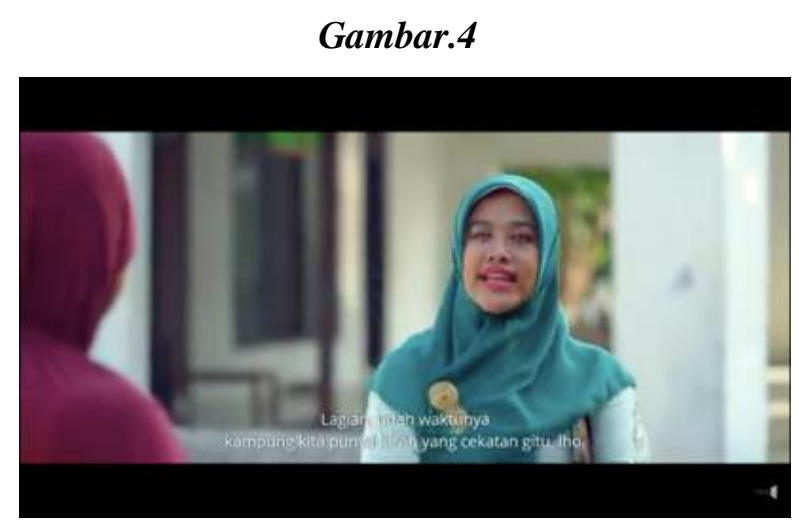

\begin{tabular}{lll}
\hline Simbol & $\begin{array}{l}\text { Deskripsi } \\
\text { Fungsi }\end{array}$ & $\begin{array}{l}\text { Deskriptif } \\
\text { Fungsi }\end{array}$ \\
\hline$\eta$ & Penghasutan & Penjahat \\
& & berusaha \\
& menghasut \\
& & para korban \\
& & dan \\
& & pahlawan. \\
& & Penjahat \\
& & berusaha \\
& & untuk \\
& & menghasut \\
\hline
\end{tabular}




\begin{tabular}{ll}
\hline korban dan \\
pahlawan \\
dengan \\
tujuan untuk \\
memperkuat \\
relasi kuasa \\
serta \\
kedekatan \\
sosial, \\
sehingga \\
penjahat bisa \\
memperoleh \\
dukungan. \\
Penjahat \\
menghasut \\
korban dan \\
pahlawan \\
dengan cara \\
kegiatan \\
gosip. \\
\hline
\end{tabular}

\section{Deskripsi}

Saat perjalanan menuju rumah sakit, seperti pada gambar 3 yang menggambarkan bahwa $\mathrm{Bu}$ Tejo selalu melakukan kegiatan bergosip mengenai hal-hal negatif dari Dian. Bu Tejo menganggap bahwa Dian merupakan wanita bermasalah, Dian menurut Bu Tejo kerap kali ditemui sedang berjalan bersama lelaki hidung belang dengan tujuan mendapatkan keuntungan lebih seperti harta. Hal ini dibuktikan pada bagian film saat $\mathrm{Bu}$ Tejo mempertanyakan harta yang dimiliki Dian saat itu, padahal Dian baru saja diterima kerja dan tidak mungkin mendapatkan finansial berlebih. Pada bagian ini $\mathrm{Bu}$ Tejo berusaha untuk memperkuat relasi kuasanya terhadap ibu-ibu di dalam truck, termasuk meyakinkan $\mathrm{Yu}$ Ning agar meyakini tentang informasi yang disampaikannya. Bagian ini sangat jelas terlihat relasi kuasa di dalam kelompok ibu-ibu pada film ini, Bu Tejo memiliki kuasa yang dominan di dalam kelompok ibu-ibu akibat dari informasi yang dimiliki $\mathrm{Bu}$ Tejo dan $\mathrm{Bu}$ Tejo terus menyebarkan pengaruh kuasanya secara tidak terorganisir. Namun dibalik kegiatan bergosip yang dilakukan $\mathrm{Bu}$ Tejo, sangat terlihat pada bagian film seperti pada gambar 4 jika Bu Tejo memiliki kepentingan personal. $\mathrm{Bu}$ Tejo berusaha menguatkan relasi kuasanya terhadap ibu-ibu untuk menarik dukungan terhadapnya dan memperkuat ikatan sosial, sebab pada bagian tersebut $\mathrm{Bu}$ Tejo memiliki kepentingan elektoral untuk bisa memenangkan suaminya agar menjadi Lurah selanjutnya. Hal ini semakin diperkuat ketika Bu Tejo memberikan uang tunai kepada Gotrek dengan diikuti percakapan halus tentang suaminya yang ingin mencalonkan diri sebagai calon Lurah, ditambah lagi ketika $\mathrm{Bu}$ Tejo menyinggung $\mathrm{Bu}$ Lurah yang sudah sering sakit-sakitan dan sudah tidak layak menjadi Lurah kembali. Sehingga dengan kata lain $\mathrm{Bu}$ Tejo memanfaatkan keadaan berkumpulnya ibu-ibu didalam truck untuk menguatkan ikatan sosial, mendominasi relasi kuasa, dan menggalang dukungan elektoral untuk suaminya. Sebab menurut (Dunbar et al., 1997), menjelaskan bahwa kegiatan bergosip berkontribusi secara positif untuk memperkuat ikatan sosial antar masyarakat.

\section{Mediasi (B)}

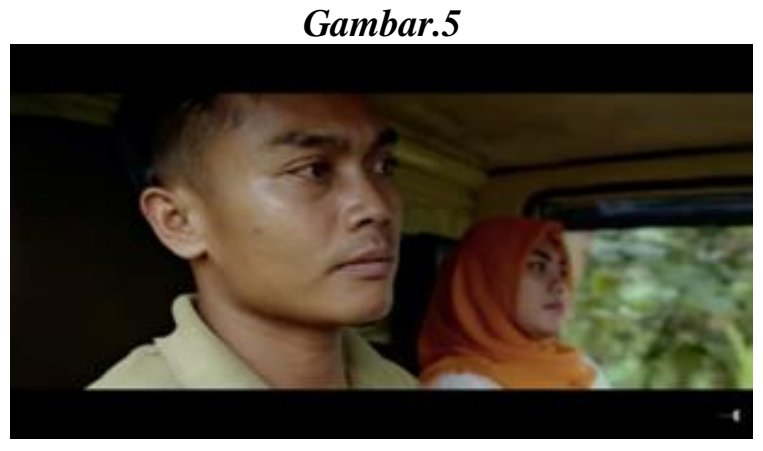

\begin{tabular}{lll}
\hline Simbol & Deskripsi & Deskriptif \\
& Fungsi & Fungsi \\
\hline B & Mediasi & Pahlawan \\
& & dan \\
& Penjahat \\
& dikirim \\
& untuk \\
& menuju \\
& tempat \\
& tertentu \\
& sebagai \\
& tujuan \\
& utama dari \\
& film yang \\
& dimaksud. \\
\hline
\end{tabular}

\footnotetext{
Deskripsi

Pada bagian ini, Yu Ning sebagai sosok pahlawan dan $\mathrm{Bu}$ Tejo sebagai sosok penjahat diantar oleh Gotrek sebagai sosok pengantar gerombolan ibu-ibu untuk menuju rumah sakit dengan tujuan menjenguk $\mathrm{Bu}$ Lurah. Pada gambar 5 terlihat Gotrek sedang mengendarai truck untuk mengantar gerombolan ibu-ibu bersama istrinya.
} 


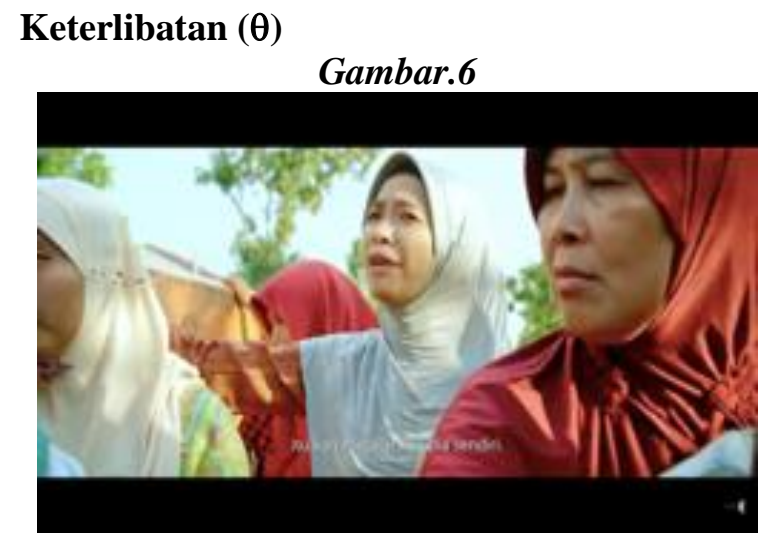

Gambar.7

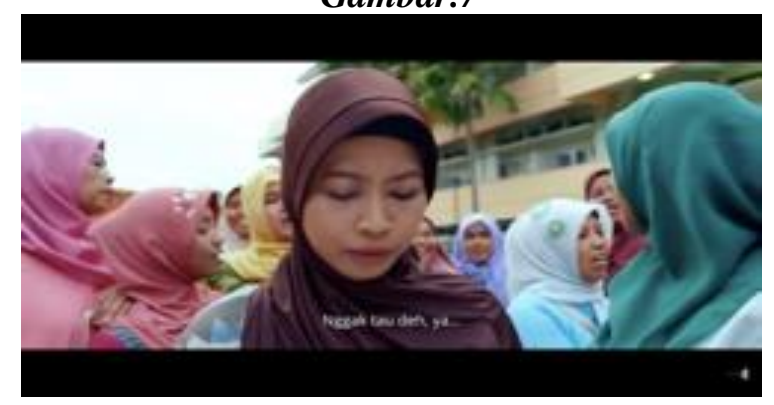

\begin{tabular}{lll}
\hline Simbol & $\begin{array}{l}\text { Deskripsi } \\
\text { Fungsi }\end{array}$ & $\begin{array}{l}\text { Deskriptif } \\
\text { Fungsi }\end{array}$ \\
\hline $\boldsymbol{\theta}$ & Keterlibatan & Para korban \\
& & terhasut oleh \\
informasi & yang \\
& & diberikan oleh \\
& & penjahat \\
& sehingga \\
& membuat para \\
& korban \\
& memberi \\
& dukungan \\
& terhadap \\
& & penjahat \\
\hline
\end{tabular}

Deskripsi

Pada bagian ini $\mathrm{Bu}$ Tejo berhasil memperkuat relasi kuasanya dengan menghasut kelompok ibu-ibu mengenai gambaran negated dari Dian. Pada gambar 6 menunjukan salah satu korban bernama $\mathrm{Bu}$ Tri berhasil dihasut oleh Bu Tejo dengan informasinya tentang Dian, sehingga $\mathrm{Bu}$ Tri pada film ini terlihat memiliki karakter yang dominan dalam mendukung tindakan $\mathrm{Bu}$ Tejo. Pada gambar 7 kuasa Bu Tejo semakin meluas kepada ibu-ibu di dalam truck, ketika $\mathrm{Bu}$ Tejo menanyakan perihal kebenaran informasi yang disampaikannya maka sontak hampir semua ibu-ibu seakan mendukungnya meski tidak se dominan Bu Tri. Pada bagian ini Yu Ning terlihat sudah terpojok.
Fungsi Pertama Seorang Penolong (D)

\section{Gambar.8}

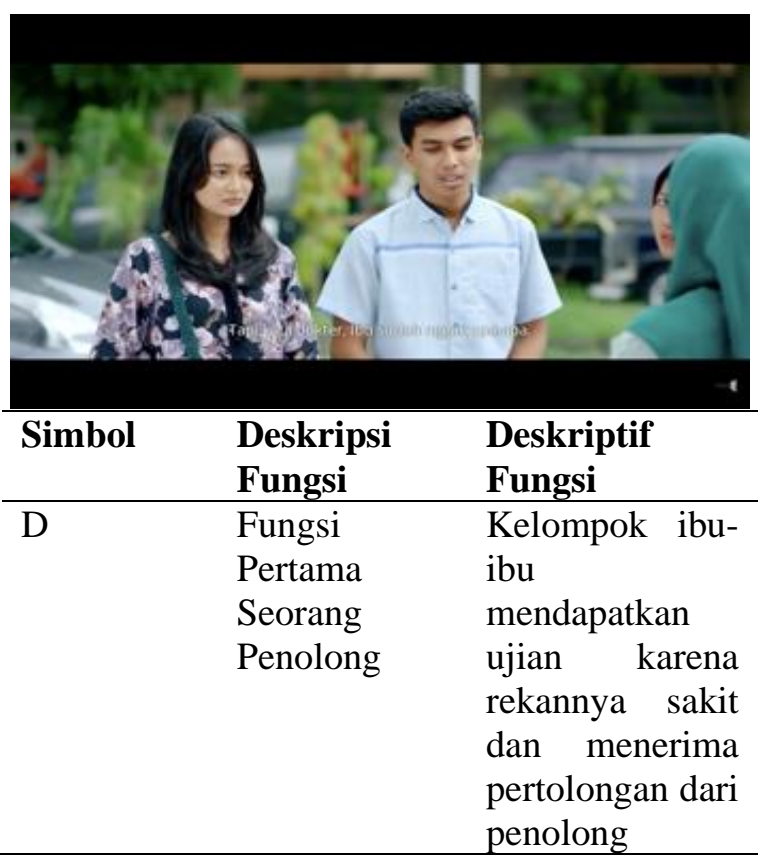

\begin{abstract}
Deskripsi
Pada bagian ini Fikri sebagai karakter penolong telah menjalankan fungsinya, Fikri membantu kelompok ibu-ibu sebagai rekan sosialnya $\mathrm{Bu}$ Lurah untuk bisa mengantarkan $\mathrm{Bu}$ Lurah ke rumah sakit karena $\mathrm{Bu}$ Lurah sedang sakit. Ditambah lagi Fikri menemani Bu Lurah di rumah sakit dan memenuhi kebutuhannya selama sakit, sehingga hal ini secara tidak langsung telah membentuk kelompok ibu-ibu dan Yu Ning sebagai pahlawan yang khawatir terhadap kondisi Bu Lurah. Dalam adegan ini ditunjukkan $\mathrm{Bu}$ Tejo sebagai penjahat tidak terlalu kecewa jika tidak bisa menjenguk $\mathrm{Bu}$ Lurah, hal ini disebabkan agenda elektoral yang dimiliki $\mathrm{Bu}$ Tejo untuk suaminya bisa menggantikan Bu Lurah sebagai Lurah baru di Desanya.
\end{abstract}

\section{Pemindahan Ruang (G)}

\section{Gambar.9}

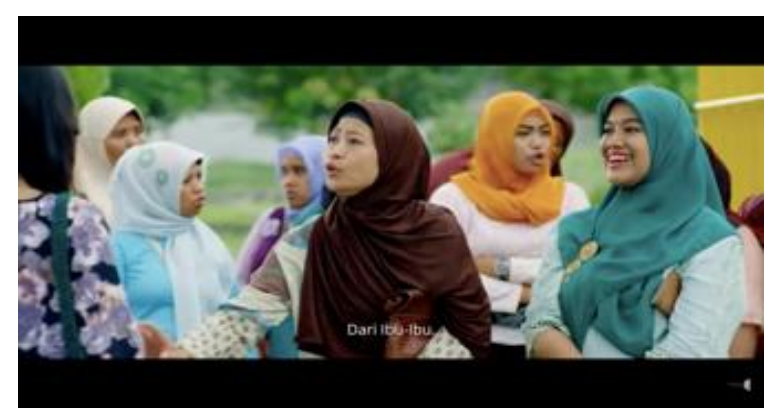




\begin{tabular}{lll}
\hline Simbol & $\begin{array}{l}\text { Deskripsi } \\
\text { Fungsi }\end{array}$ & $\begin{array}{l}\text { Deskriptif } \\
\text { Fungsi }\end{array}$ \\
\hline G & Pemindahan & Pahlawan \\
& Ruang & mengarah \\
& & pada objek \\
& & yang \\
& & diselidiki. \\
\hline
\end{tabular}

\begin{tabular}{l}
\hline Deskripsi \\
\hline Pada bagian ini Yu Ning sebagai sosok \\
pahlawan telah berpindah dari truck menuju \\
rumah sakit dan bertemu dengan Fikri sebagai \\
penolong, sehingga Yu Ning bisa menanyakan \\
kondisi terbaru dari Bu Lurah yang tengah sakit \\
di rumah sakit. Terlihat pada gambar 9 Yu ning \\
memberikan amplop berisi uang tunai hasil dari \\
sumbangan kelompok ibu-ibu, guna untuk \\
membantu meringankan beban Bu Lurah yang \\
tengah sakit di rumah sakit.
\end{tabular}

\section{Perjuangan (H)}
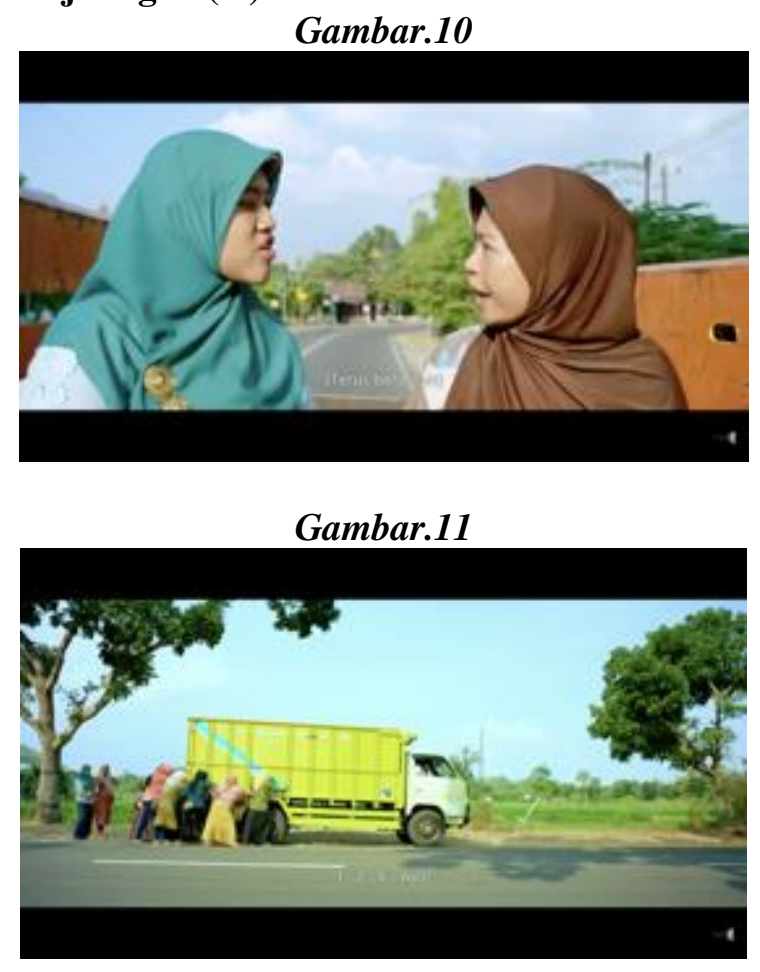

Gambar.12

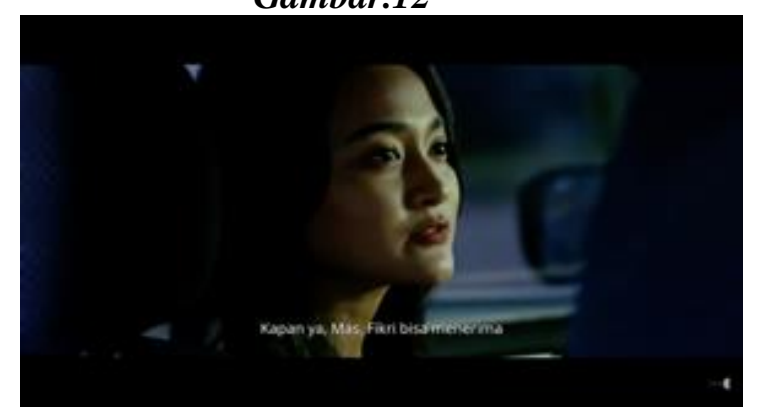

\begin{tabular}{lll}
\hline Simbol & $\begin{array}{l}\text { Deskripsi } \\
\text { Fungsi }\end{array}$ & $\begin{array}{l}\text { Deskriptif } \\
\text { Fungsi }\end{array}$ \\
\hline H & Perjuangan & Pahlawan dan \\
penjahat \\
bertarung \\
argumen \\
& secara \\
& langsung. \\
& Pahlawan \\
& berada di satu \\
& tempat yang \\
& sama dengan \\
& penjahat, \\
& bertarung \\
& argument \\
& untuk merebut \\
& relasi kuasa. \\
& Pahlawan juga \\
& turut berjuang \\
& untuk \\
& membantu \\
& proses \\
& menyelidiki \\
& objek terkait. \\
\hline
\end{tabular}

\begin{tabular}{l}
\hline Deskripsi \\
\hline Pada gambar 10 adalah bagian dimana Yu Ning \\
sebagai sosok pahlawan dan Bu Tejo sebagai \\
sosok penjahat sempat beradu argument \\
mengenai kebenaran informasi mengenai Dian. \\
Pada bagian ini Yu Ning dan Bu Tejo berusaha \\
meyakinkan bahwa setiap dari mereka \\
memiliki argument yang paling benar, \\
sehingga dengan tujuan untuk bisa \\
mempengaruhi kelompok ibu-ibu dengan \\
informasi yang mereka miliki. Artinya bahwa \\
Bu Tejo dan Yu Ning tengah berebut relasi \\
kuasa untuk menentukan siapa yang akan lebih \\
dominan, tentu saja setiap dari mereka berdua \\
memiliki tujuanya masing-masing. Bu Tejo \\
memiliki kepentingan kuasa untuk merekatkan \\
hubungan sosial antar individu dan \\
menggalang dukungan elektoral suaminya, dan \\
Yu Ning memiliki kepentingan untuk \\
menyadarkan ibu-ibu sekaligus Bu Tejo bahwa \\
bergosip merupakan kegiatan buruk, disisi \\
yang sama Yu Ning mencoba untuk membela \\
Dian karena Dian adalah saudara dari Yu Ning, \\
meskipun pada akhirnya seperti pada gambar \\
12 yang menunukan bahwa tuduhan negative \\
Bu Tejo terhadap Dian adalah benar dan hal ini \\
sekaligus menggambarkan bagaimana Dian \\
menghianati perjuangan Yu Ning. Perjuangan \\
Yu Ning sebagai pahlawan juga dibuktikan \\
\hline
\end{tabular}


pada gambar 11 yaitu saat Yu Ning turut andil dalam mendorong truck yang tengah mogok, dengan tujuan untuk mempermudah tujuan awal kelompok ibu-ibu agar bisa menjenguk $\mathrm{Bu}$ Lurah sebagai objek yang dituju. Namun dalam bagian ini justru $\mathrm{Bu}$ Tejo tidak membantu mendorong sama sekali.

\section{Tugas berat (M)}

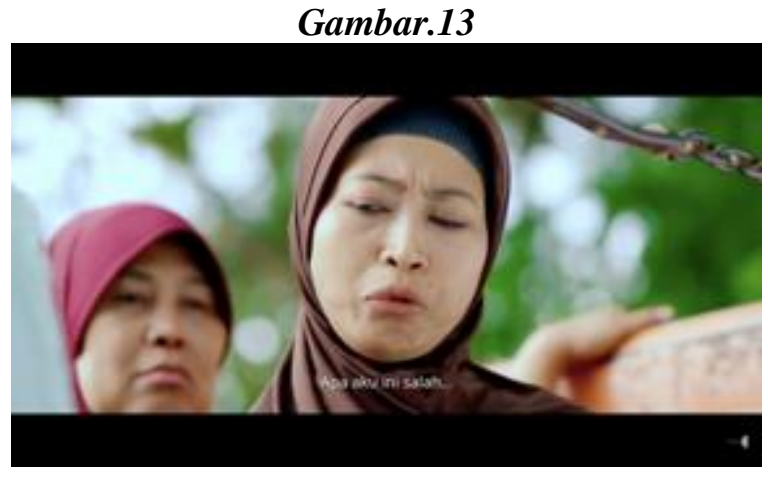

Gambar.14

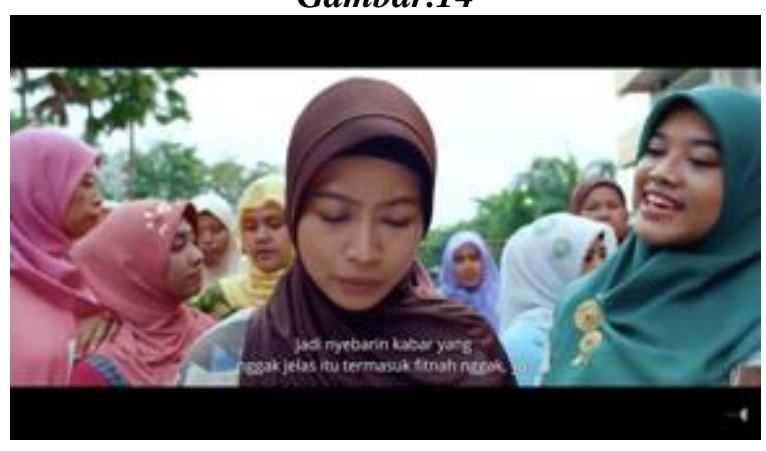

\begin{tabular}{lll}
\hline Simbol & $\begin{array}{l}\text { Deskripsi } \\
\text { Fungsi }\end{array}$ & $\begin{array}{l}\text { Deskriptif } \\
\text { Fungsi }\end{array}$ \\
\hline M & Tugas Berat & Palawan \\
& & diberikan ujian \\
& untuk \\
& membuktikan \\
& & dirinya benar \\
& dalam bertindak \\
& & atas \\
& & permasalahan \\
& & yang terjadi \\
\hline
\end{tabular}

\begin{tabular}{l}
\hline Deskripsi \\
\hline Pada bagian seperti Digambar 13, \\
menggambarkan kondisi Yu Ning sebagai \\
pahlawan yang tengah sedih akibat dari \\
keputusannya yang terburu-buru untuk \\
menjenguk Bu Lurah yang pada akhirnya \\
berujung pada kekecewaan ibu-ibu yang tidak \\
bisa menjenguk Bu Lurah akibat dari Bu Lurah \\
yang masih di ruang ICU dan belum \\
diperbolehkan untuk dijenguk. Dengan kondisi \\
\hline
\end{tabular}

seperti ini, kondisi dimana Yu Ning sedang berada diposisi yang tidak stabil, seperti pada gambar $14 \mathrm{Bu}$ Tejo sebagai penjahat terus berusaha menguatkan relasi kuasanya dengan meyakinkan kelompok ibu-ibu lainnya mengenai kebenaran informasi yang $\mathrm{Bu}$ Tejo miliki. Dalam bagian ini terlihat Yu Ning tidak bisa melakukan tugasnya sepagai pahlawan untuk menyelamatkan citra Dian, karena tugasnya sudah terlampau berat akibat dari kuasa $\mathrm{Bu}$ Tejo yang berhasil meyakinkan ibuibu lainya atas informasi yang Bu Tejo miliki.

\section{Solusi (N)}

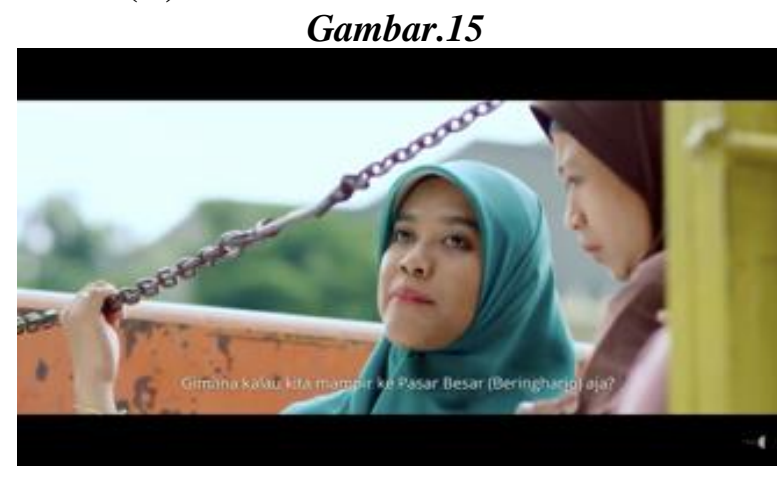

\begin{tabular}{lll}
\hline Simbol & $\begin{array}{l}\text { Deskripsi } \\
\text { Fungsi }\end{array}$ & $\begin{array}{l}\text { Deskriptif } \\
\text { Fungsi }\end{array}$ \\
\hline $\mathrm{N}$ & Solusi & Solusi dari \\
& & kegagalan \\
& & melakukan \\
& kegiatan seperti \\
& & yang \\
& & direncanakan \\
\hline
\end{tabular}

\begin{tabular}{l}
\hline Deskripsi \\
\hline Dalam bagian ini telah diketahui bahwa para \\
ibu-ibu tidak bisa menjenguk Bu Lurah karena \\
Bu Lurah masih berada di ruang ICU dan \\
belum bisa untuk dijenguk, hal ini disampaikan \\
oleh Fikri secara langsung. Hal ini sontak \\
membuat kelompok ibu-ibu kecewa, sebab \\
mereka sudah menempuh perjalanan yang \\
cukup jauh untuk menjenguk Bu Lurah namun \\
tidak bisa menjenguknya. Namun seperti apa \\
yang digambarkan pada Gambar 15, Bu Tejo \\
memberikan solusi kepada kelompok ibu-ibu \\
untuk pergi ke Pasar Bringharjo untuk \\
berbelanja sesuatu, hal ini dilakukan demi \\
menutupi kesia-siaan ibu-ibu yang sudah \\
menempuh jarak begitu jauh namun tidak bisa \\
melakukan kegiatan yang direncanakan dari \\
awal, yakni menjenguk Bu Lurah.
\end{tabular}




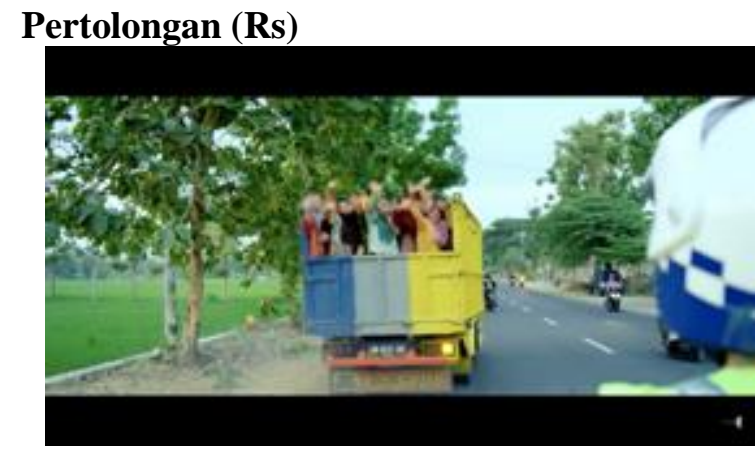

Gambar.16

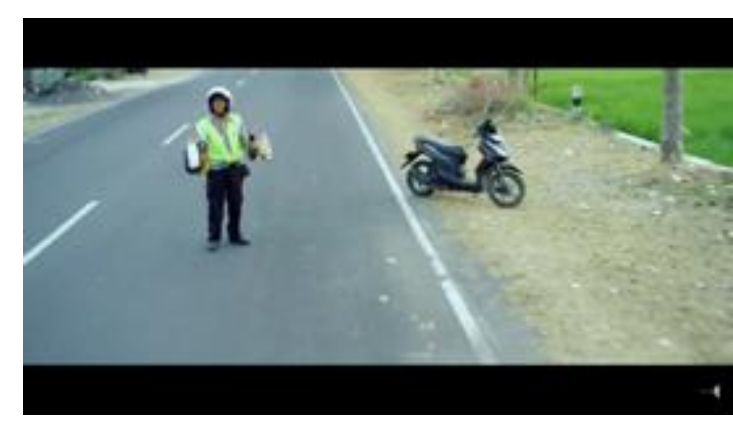

Gambar.17

\begin{tabular}{lll}
\hline Simbol & $\begin{array}{l}\text { Deskripsi } \\
\text { Fungsi }\end{array}$ & $\begin{array}{l}\text { Deskriptif } \\
\text { Fungsi }\end{array}$ \\
\hline Rs & Pertolongan & Pahlawan \\
& & diselamatkan \\
& oleh kelompok \\
& & sosial dari hal \\
& & yang dapat \\
& & menghambat \\
& & dirinya menuju \\
& & hal yang dituju. \\
\hline
\end{tabular}

dikendarai nya dari tindakan tilang polisi, dan seperti yang ada pada gambar 17 bahwa ibu-ibu memberikan polisi barang-barang tertentu agar bisa lepas dari tindakan tilang yang dilakukan polisi.

\section{Hukuman (U)}

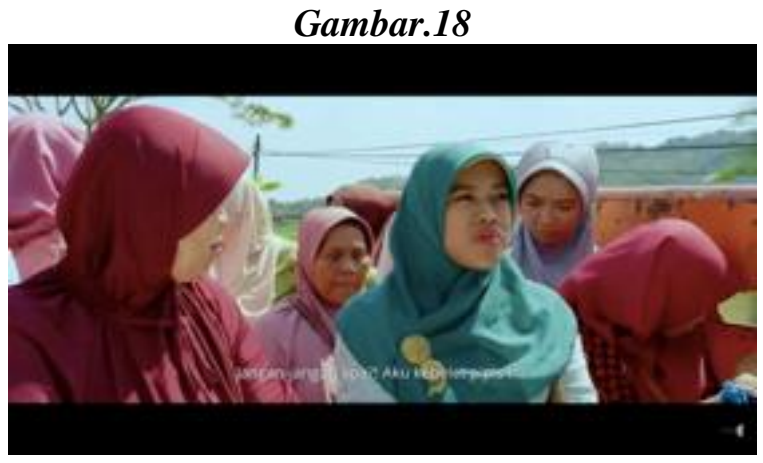

Gambar.19

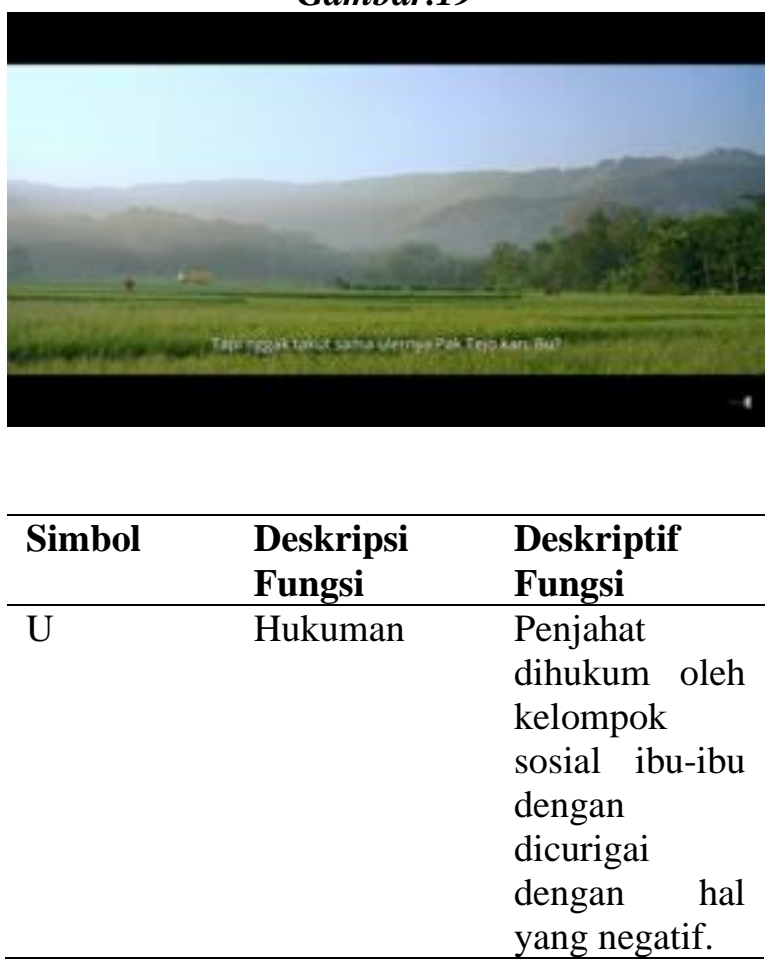

\begin{tabular}{l}
\hline Deskripsi \\
\hline Pada bagian seperti di gambar 18, Bu Tejo \\
merasa ingin sekali buang air kecil. Namun \\
kelompok ibu-ibu mulai mencurigai Bu Tejo \\
dengan hal-hal negatif, hal ini dibuktikan \\
dengan kata "wah, jangan-jangan..." yang \\
dilayangkan oleh kelompok ibu-ibu terhadap \\
Bu Tejo. Hal ini terjadi sebab bagian saat Bu \\
Tejo 'kebelet' buang air kecil adalah bagian \\
yang bertepatan setelah Bu Tejo menganggap \\
Dian hamil diluar nikah, dan Bu Tejo mulai \\
memegang perutnya akibat ingin buang air \\
kecil. Hal ini sontak membuat ibu-ibu curiga \\
\hline
\end{tabular}

Deskripsi

Di dalam perjalanan, truck yang dikendarai oleh Gotrek dengan diisi oleh kelompok ibuibu di belakangnya sempat dihadang oleh polisi untuk ditilang, sebab dalam peraturan berkendara penggunaan truck untuk mengangkut kerumunan adalah sebuah tindakan pelanggaran berkendara, sehingga tindakan menilang ini berpotensi untuk menghambat perjalanan $\mathrm{Yu}$ ning beserta ibuibu lainnya untuk menjenguk $\mathrm{Bu}$ Lurah. Sehingga hal ini sontak membuat ibu-ibu di dalam truck marah kepada polisi, kemarahan ibu-ibu kepada polisi tidak hanya diakibatkan oleh polisi yang menilang Gotrek dan truknya, namun tidak lepas juga dari peran $\mathrm{Bu}$ Tejo dengan relasi kuasanya yang dominan yang turut menjadi kompor bagi kemarahan ibu-ibu. Seperti pada gambar 16 memperlihatkan bahwa ibu-ibu berhasil menyelamatkan truck yang 
bahwa Bu Tejo juga hamil, meskipun pada film ini sudah diterangkan bahwa Bu Tejo memiliki suami, namun diksi kata yang dikeluarkan oleh kelompok ibu-ibu pada bagian gambar 18 terkesan berpikiran negatif kepada $\mathrm{Bu}$ Tejo yang gemar bergosip. Disisi lain Gotrek meminta $\mathrm{Bu}$ Tejo untuk buang air kecil di sawah, meskipun pada akhirnya tetap mencari tempat yang layak agar Bu Tejo bisa buang air kecil.

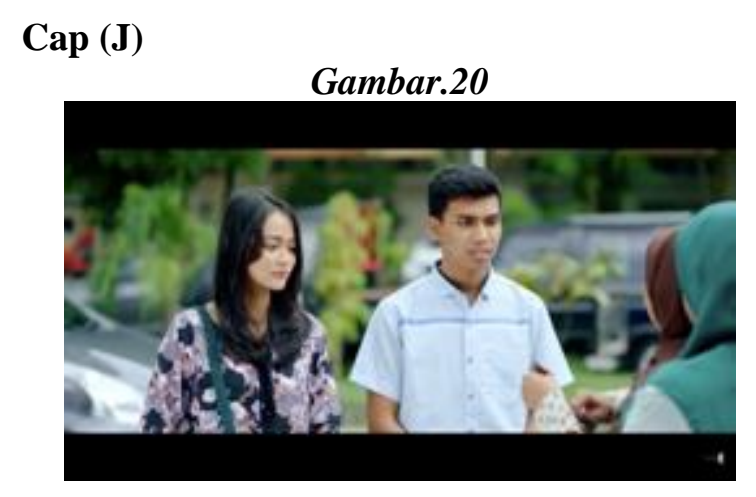

Gambar.21

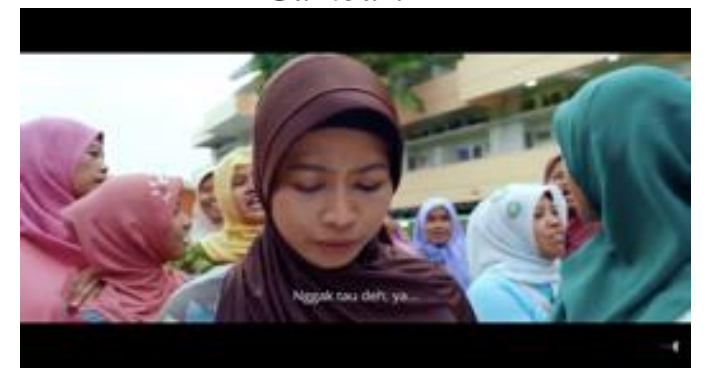

\begin{tabular}{lll}
\hline Simbol & $\begin{array}{l}\text { Deskripsi } \\
\text { Fungsi }\end{array}$ & $\begin{array}{l}\text { Deskriptif } \\
\text { Fungsi }\end{array}$ \\
\hline J & Cap & Karakter Putri \\
& & dikenal \\
& memiliki \\
& & sosok yang \\
& negatif dan \\
& berbahaya bagi \\
& & kelompok \\
& & sosial \\
\hline
\end{tabular}

\footnotetext{
Deskripsi

Dalam bagian ini karakter Dian telah dikenal sebagai wanita yang bermasalah, Dian dikenal sebagia wanita yang suka memanfaatkan harta dari lelaki hidung belang. Hal ini dibuktikan dengan gambar 21 tentang perilaku ibu-ibu yang sudah mulai mendukung informasi dari $\mathrm{Bu}$ Tejo, hal ini sekaligus membuktikan keberadaan dominasi kuasa Bu Tejo atas ibuibu dengan informasi yang dimilikinya.
}

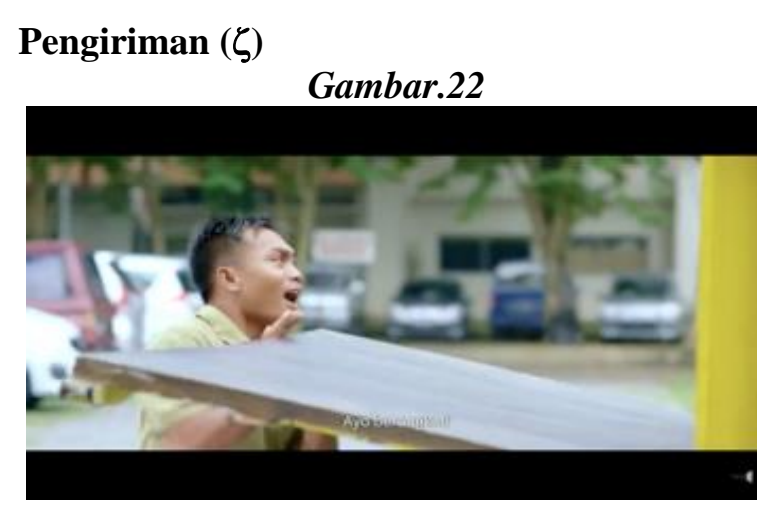

\begin{tabular}{lll}
\hline Simbol & $\begin{array}{l}\text { Deskripsi } \\
\text { Fungsi }\end{array}$ & $\begin{array}{l}\text { Deskriptif } \\
\text { Fungsi }\end{array}$ \\
\hline$\zeta$ & Pengiriman & $\begin{array}{l}\text { Kelompok } \\
\text { sosial dikirim } \\
\text { ketempat baru }\end{array}$ \\
\hline
\end{tabular}

\begin{tabular}{l}
\hline Deskripsi \\
\hline Setelah mengetahui bahwa Bu Lurah tidak bisa \\
dijenguk, maka kelompok ibu-ibu memutuskan \\
untuk pergi kepasar Bringharjo dengan tujuan \\
untuk berbelanja.
\end{tabular}

\section{Representasi Relasi Kuasa Pada Film Pendek} Tilik

Selaras dengan yang disampaikan oleh Michel Foucault, bahwasanya pada sebuah interaksi sosial pada masyarakat, terdapat sebuah relasi yang memiliki keterkaitan satu sama lain namun tidak merata peran nya, dengan kata lain ada yang dikuasai dan ada yang menguasai karena pengetahuan. Singkatnya adalah tidak ada praktek pelaksanaan kekuasaan yang tidak memunculkan pengetahuan dan tidak ada pengetahuan yang di dalamnya tidak memandang relasi kuasa (Foucault \& Muzir, 2002).

Di dalam film pendek Tilik yang telah dianalisis menggunakan Kerangka Analisis Vladimir Propp, sudah dapat menggambarkan bagaimana peran relasi kuasa antara aktor-aktor yang berperan dalam film tersebut. Hal yang sangat nampak adalah tentang pendistribusian relasi kuasa atas pengetahuan yang dimiliki oleh 
para pemain. Dialog antara Bu Tejo dengan warga lain di bak truk serta dialog nya dengan polisi yang melakukan penilangan, merupakan representasi kehidupan keseharian dan memiliki nilai kepentingan. Kepentingan $\mathrm{Bu}$ Tejo adalah untuk memenangkan suaminya menjadi kepala desa dan menyingkirkan Dian yang dianggap sebagai distraksi dalam kelompok masyarakat. Hal yang dilakukan oleh $\mathrm{Bu}$ Tejo adalah untuk menghimpun kekuasaan atas informasi yang diperolehnya dari Internet, dan disebarkan secara masif kepada seluruh pemain di dalam film secara tidak ter lembaga.

Relasi antara $\mathrm{Bu}$ Tejo dengan semua pemain dalam film tersebut merupakan sebuah bentuk relasi kuasa, seperti yang dijelaskan Foucault tentang individu modern muncul sebagai objek dan subjek dari penyebaran dan pengadaan jaring-jaring kuasa. Menurut pandangan Foucault, kehadiran dari kekuasaan tersebar dimana-mana, pasalnya kekuasaan adalah satu dimensi dari satu relasi yang terpadu. Artinya bahwa dimana ada sebuah relasi, maka ada sebuah kekuasaan di dalamnya (Susilo \& Kodir, 2016). Foucault memberi pengakuannya bahwa ada kehadiran dari sekian banyak kekuatan dan kuasa yang tersebar secara luas dalam relasi antar manusia. Semua kekuatan dan kuasa itu dapat ditemukan dai berbagai aspek relasi antar manusia, contohnya seperti relasi antara manusia satu dengan manusia lainnya dan relasi antar manusia dengan lingkungannya/situasi mereka (Bertens. K, 2001). Apa yang disampaikan oleh Foucault lebih membahas mengenai bagaimana sebuah kuasa dapat berfungsi di bidang tertentu, pada konteks penelitian ini adalah relasi kuasa atas informasi yang dimiliki oleh $\mathrm{Bu}$ Tejo terhadap para pemain di film tersebut.

\section{Penutup}

Dalam film pendek dengan tajuk Tilik ini menceritakan tentang budaya masyarakat jawa yang gemar menengok kerabatnya yang sakit dengan bergerombol (beramai-ramai), hal yang ditonjolkan sudah tentu bagaimana mereka menggunakan truk sebagai alat transportasinya. Namun dalam upaya untuk menjenguk kerabatnya (dalam konteks ini $\mathrm{Bu}$ Lurah), perdebatan panjang pun terjadi karena $\mathrm{Bu}$ Tejo melayangkan informasi mengenai Dian dan mulai untuk bergosip untuk mempengaruhi kelompok ibu-ibu serta untuk kepentingan elektoral suami dari Bu Tejo.

Tentunya simbol mengenai relasi kuasa atas informasi di film pendek dengan tajuk Tilik ini sangat nampak. Film pendek dengan tajuk Tilik ini berhasil memotret relasi kuasa atas informasi dikalangan ibu-ibu pada kelompok masyarakat sosial yang tradisional, dalam konteks ini sangat terlihat bagaimana $\mathrm{Bu}$ Tejo menyebarkan jarring relasi kuasanya secara tidak ter lembaga. Tujuanya untuk melanggengkan kepentingannya yaitu mengenai kemenangan elektoral suaminya sebagai calon lurah dan menyingkirkan Dian yang dianggap sebagai distraksi di dalam kelompok masyarakat.

\section{Daftar Pustaka}

Bertens. K. (2001). Filsafat Barat Kontemporer. In Jakarta: PT Gramedia Pustaka Utama.

Chariri, A. (2009). Landasan filsafat dan metode penelitian kualitatif. In 
Workshop Metodologi Penelitian Kuantitatif dan Kualitatif, Laboratorium Pengembangan Akuntansi (LPA), Fakultas Ekonomi Universitas Diponegoro Semarang, 31 Juli -1 Agustus 2009.

Dunbar, R. I. M., Marriott, A., \& Duncan, N. D. C. (1997). Human conversational behavior. Human Nature. https://doi.org/10.1007/BF02912493

Eriyanto. (2015). Analisis Naratif: Dasardasar dan Penerapannya dalam Analisis Teks Berita Media. Prenada Media.

Fitriasari, I. (2016). Membaca Film Indonesia Bertema Religi (Studi Film Discourse Interpretation Tentang Identitas Keislaman dalam Film 99 Cahaya Di Langit Eropa dan Haji Backpacker) [Universitas Airlangga]. http://repository.unair.ac.id/45699/

Foucault, M., \& Muzir, I. R. (2002). Menggugat Sejarah Ide. IRCiSoD (Institute for Religion and Civil Society Development).

Humairoh, N. Y., \& Chirstantyawati, N. (2018). Representasi Relasi Kuasa Negara Adidaya Amerika Dalam Film Geostrom. Jurnal Komunikasi Universitas Garut: Hasil Penelitian Dan Pemikiran, 4(2). https://doi.org/http://dx.doi.org/10.1035 8/jk.v4i2.484
Mudhoffir, A. M. (2013). Teori Kekuasaan Michel Foucault: Tantangan bagi Sosiologi Politik. MASYARAKAT: Jurnal Sosiologi. https://doi.org/10.7454/mjs.v18i1.3734

Nugroho, C. (2019). Relasi Kuasa Media Dan Isu Gender Dalam Program Televisi di Indonesia. ProTVF. https://doi.org/10.24198/ptvf.v2i2.2081 6

Pratista, H. (2008). Memahami Film. Homerian Pustaka.

Sobur, A. (2003). Semiotika komunikasi. Remaja Rosdakarya.

Sobur, A. (2014). Komunikasi Naratif Paradigma, Analisis, dan Aplikasi. PT Remaja Rosdakarya.

Soekanto, S. (1990). Sosiologi Suatu Pengantar, Edisi IV. In Jakarta, Penerbit Rajawali.

Soemardjan, S., \& Soemardi, S. (1964). Setangkai Bunga Sosiologi. In SETANGKAI bunga sosiologi.

Susilo, D., \& Kodir, A. (2016). Politik Tubuh Perempuan: Bumi, Kuasa, dan Perlawanan. Jurnal Politik. https://doi.org/10.7454/jp.v1i2.19

Syahputra, I. (2017). Post Media Literacy: Menyaksikan Kuasa Media Bersama Michel Foucault. Jurnal ASPIKOM. https://doi.org/10.24329/aspikom.v1i1.4 